\title{
Chinese Outward Direct Investment in Australia: Current Condition Analysis and Prospect*
}

\author{
Xuezhen Kang \\ Master of Finance, CBE, Australian National University. \\ Address: 22 Bingham Circuit, Kaleen, Canberra, ACT 2617, Australia.
}

Email: kchxz1506@163.com

\begin{abstract}
Australia has become a crucial destination for Chinese foreign investment. Based on statistical data of Chinese outward direct investment (ODI) in Australia throughout recent ten years, by practicallyanalyzing the development and current condition of Chinese ODI in Australia, this paper discusses problemsof Chinese ODI in Australia, brings forward specific countermeasures and recommendations, and makes a prospect for its future development. Findings suggest thatChinese enterprises invest in Australia basically because of Australian resources' reservation, Chinese domestic demand for various kinds of goods, and the support of relevant favorable policies. The outcomes also suggest that Chinese ODI in Australia has main characteristics of metal and energy industry dominance, imbalanced industrial and regional investment allocations as well as the tendency of industrial diversification. To improve imperfections, Chinese enterprises shall promote the industrial diversification further and to get ready knowledge about Australian foreign policies and local regulations, and Chinese government are supposed to bring forward more encouraging policies for private enterprisesto invest abroad.In general, there still exist a great potential anda prosperous prospect for Chinese enterprises to invest in Australia.
\end{abstract}

Keywords: Chinese ODI in Australia; China; Australia; metal and energy industry; foreign investment; Chinese SOEs.

\section{Introduction}

Ever since 1970s, under the orientation of a series of national policies including "reform and opening up", "attracting investments", "bringing in" and "going global" strategies, the development of both Chinese industrial technologies and enterpriseshas fundamentallyexperienced changes from nonexistence to existence, changes from being backward to advancement and changes from the dominance of "bringing in" to the coordination between "bringing in" and "going global", and the industrial fund has got accumulated and expanded. From the perspective of operating scale, a great many Chinese enterprises have already aimed at overseas market instead of solely Chinese inbound market and have aggressively kept investing outbound and running globalized operation; from the perspective of foreign economic trade,China has stepped into the rank of great power in terms of foreign investment.

As a developed country withample natural resources, Australia occupies a significant status of the foreign investment of China. In accordance to statistical data of Chinese outward direct investment (ODI) in Australia during recent ten years, on the fundament of practically analyzing development and current condition of Chinese ODI in Australia, this paper is going to discuss and summarize problems existing in Chinese ODI in Australia currently, to bring forward specific countermeasures and recommendations, and to make a prospect of development ofChinese ODI in Australia.

*This paper is supported by the National Social Science Fund General Project (16BJL039) and the Social Science Fund General Project of Heilongjiang Province (15GJD03). 


\section{The Origin and Development}

Chinese foreign investment started to occur at the end of $1990 \mathrm{~s}$ and the beginning of the $21^{\text {st }}$ century. Around the end of 1990s, Chinese capital flows began to be revealed as capital outflowat a relatively low level, and after entering $21^{\text {st }}$ century, the total volume of Chinese capital outflow started to climb up. Till now, Chinese capital outflows have still been fluctuating around the level of USD 400 HML (USD 40 billion) annually on average.

It was not until 2005 that Chinese enterprises started to invest in Australia. ${ }^{1}$ In 2005, ChineseODI in Australia amounted to USD 320 million, and afterward Chinese enterprises kept investing in Australia incredibly actively with annual investment amounts no lower than USD 2 billion, creating records of USD 15.99 billion in 2008 and USD 11.98 billion in 2015 respectively. Generally, Chinese ODI in Australia experienced large fluctuation, which was convergent to Chinese capital outflows fluctuation during the same period. Observed from the scale of investment volume, Chinese investing enterprises generally hold an optimistic attitude towards investing in Australia.

\section{Reasons and Motives}

\subsection{Australian Resource Advantage and Its Characteristics}

Australia is abundant in natural mineral and energy resources, including bauxite, coal, iron ore, copper, tin, gold, silver, uranium, nickel, tungsten, rare earth elements, mineral sands, lead, zinc, diamonds, natural gas, petroleum [1], and Australia thus has a comparative advantage in relevant resources trading. Australian net export volume of coal accounts for $29 \%$ of the global total volume of that, becoming the largest coal net export country in the world [1]. From 2005 to 2015, in terms of energy trade, the export volume always far exceeded the import volume in each year with the annual average net export of AUD 7950.02 million at annual average growth rate of $5.39 \%$.

In terms of the geographical distribution of natural resources, the majority distributes among the states $^{2}$ and regions that are relatively remote. The exploration volume of WA took up 59.38\% out of the total, followed by that of QLD $(16.90 \%)$ and that of SA $(12.12 \%)$, which accounted for nearly $90 \%$ of total mineral and petroleum exploration in Australia. Remote as those regions are, those regions contain more ample mineral and energy resources compared with other regions.

As for the non-natural resources such as human resources, financial resources, those tend to gather in the regions where populations are relatively intensive. As for proportions of households in each state in 2015, NSW (31.39\%), VIC (24.98\%) and QLD (20.16\%) ranked top 3, which altogether took up over three-fourth (76.53\% in practice) of total households within Australia.

In addition, economy and economic development of each state are highly related to its foreign trade and that to what extent a state can attract foreign investment. The export volume and import volume of NSW, VIC, QLD and WA all transcended that of other states in 2015, which means that international trades in those regions were comparatively active. NSW and VIC for particular have relatively long history of economic development and economic fundament, so a large quantity of Australian companies and multi-national companies (MNCs) set their branches or even headquarters there, which leads to relatively efficient information flows and comparatively high capital liquidity. Accordingly, although NSW and VIC are poor of natural resources in comparison with other regions, the service trading is generally more active comparably.

\footnotetext{
${ }^{1}$ Before 2005, the balance of Chinese ODI in Australia remained zero. See The Treasury of Australia Government, $<$ Treasury Working Paper 2016-01: Foreign Investment into Australia>.

${ }^{2}$ Australia is constituted by New Sales Wales (NSW), Victoria (VIC), Queensland (QLD), South Australia (SA), Western Australia (WA), Tasmania (TAS), Northern Territory (NT), and Australian Capital Territory (ACT).
} 


\subsection{The Need for Chinese National Economic Development}

Chinese ODI in Australia is carried out to satisfy the need for Chinese industrial development and national economic development. For long, the development of heavy industries with high consumption within China in areas of steel production, concrete production, etc. has stimulated the demand for resources like metal and energy resources. As researched by World Steel Association and World Energy Consumption \& Statistics, China has always been the nation with largest steel-production and energy consumption volume in the world which have continuously been ascending. Under this circumstance, Chinese large mineral and energy industrial enterprises transfer their investments to Australia to expand their economic scales.

Chinese ODI also results from the incentive to satisfy the demand of Chinese domestic consumption. China is currently at the stage of transforming from a middle-income country into a high-income country, and in the developed regions such as Pearl River Delta and Yangtze River Delta, the income levels have already approximately been equivalent to that of upper-middle countries[2].The enhancement of income level enables Chinese consumption structure to step into the stage of developing new type of consumption ${ }^{3}$ from the stage of material, surviving, conventional consumption with major goal of solving the subsistence problem (clothing and food)[3],leading to mounting demand for energy as well as a variety of products with high-quality, which effectively spurs and expands Chinese ODI in Australia in multiple industries.

\subsection{Relevant Favorable Policies Released}

Ever since December 21, 1971 when Sino-Australiandiplomatic relationship was established, through the leaders' frequent contacts and mutual visits, bilateral political, economic and trade relationship has been well developed, and communications and collaborations have been developed sustainably and stably. In order to expand Chinese enterprises' overseas investments, Chinese government has released a series of favorable policies for investing overseas in succession. The document of $<$ Opinions about Encourage and Regulate Foreign Investment Cooperation $>$ improved and released in 2007, for example, indicates Chinese government's will to encourage and promote Chinese enterprises to invest overseas, providing policies and institutional conditions to motivate mutually respectful and reciprocitarian investments and trades between China and other countries. In addition, Australian government has also taken a series of political actions favorable for FDI and its foreign investment, therefore promoting Sino-Chinese trades and investments. Especially China-Australia Free Trade Agreement (ChAFTA, negotiated on June 17, 2015)is expected not only to promote Chinese ODI in Australia but also tostimulate Australian economy. M\&A of Australian local enterprises by Chinese enterprises may provide additional funds or human resources and more local employment opportunities. Also, with the investment volume and Chinese investing enterprises increasing, Australian market competition can possibly be intensified, which will develop and complete local market regime further.

\section{Characteristics and Issues}

\subsection{Dominance of Metal and Energy Industry}

The investments are basically dominated by metal and energy industry, albeit large amounts of Chinese ODI in Australia in recent years annually. Among the accumulated investments from 2005 to June 2016 , metal industry $(40.10 \%)$ took the lead, and energy industry (36.40\%) ranked second

\footnotetext{
${ }^{3} \mathrm{New}$ Type of Consumption refers to the sustainable development that is based on the "people-oriented" idea and aims to maximize the satisfaction of reasonable consumption, characterized by major group of consumers popularized, consumption products greenized, consuming behavior civilized, consumption environment ecologicalized, etc., as which in the area of consumption coordinative development among material civilization, spirit civilization and ecological civilization is revealed.See F. Chi in: Understand the "New Normal" of Chinese Economy, edited by China Workers Publishing House, Beijing (2015), p. 301.
} 
only to it, which accounted for $76.5 \%$ altogether, remaining portion shared by other industries.However, due to the global economic downturn in recent several years, the growth rate of Chinese economy slowing down ${ }^{4}$ and the transformation of Chinese economy development from being "production motivated" into being "consumption motivated", 5 the expansion ofAustralian metal and energy industry has been seriously affected and constrained. According to the statistical data of Australian Securities Exchanges (ASX), the performance indicators of metal sector and energy sector have generally revealed a downward tendency, and companies of those two sectors have suffered depression comparably [4].Also, influenced by the prices of staple commodities falling down, the Chinese investment influx to Australian mineral industry slumped (down 85\% year-on-year), with Chinese foreign investment in Australia dropping by nearly 20\% [5].

\subsection{Imbalanced Distribution of Regional and Industrial Investments}

Influenced by Australian demographic and resource distribution, Chinese ODI in Australia is characterized by large regional differences in the aspect of investing regions and industries and imbalanced regional distribution.Chinese ODI is extremely intensive in NSW and VIC, relatively intensive in QLD, NT, SA and WA and rare in ACT and TAS.NSW attracted 49.3\% of Chinese ODI in 2015, above that of other states. VIC attracted $33.58 \%$ ODI from China, ranking second only to NSW, followed by QLD (9.05\%), NT (3.74\%), SA (3.58\%) and WA (0.76\%). By contrast, ACT and TAS attracted zero ODI from China, i.e. these two states did not attract or attracted a very tiny amount of investment from China in 2015 (see Fig.1).

Figure 1. Chinese ODI in Australia by State and the Proportions in 2015

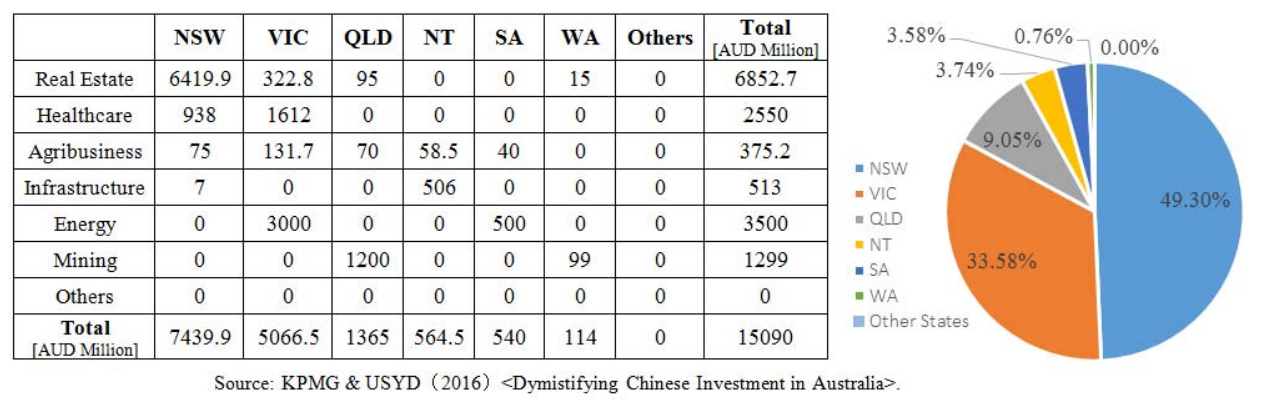

From the perspective of regional distribution of industries, Chinese ODI in real estate distributed in NSW, VIC, QLD and WA, but intensively in NSW (42.54\% of total ODI). Investment in agribusiness spread most widely, distributing in all states except WA, but with the lowest proportion; the volume of infrastructure investment was only higher than that of agribusiness, intensively distributing in NSW and NT; the investments in energy industry and mining industry intensively distributed in VIC and SA.

\subsection{Tendency of Industries and Investing Principals Diversifying}

During the period between 2005 and June 2016, Chinese ODI in Australia development has implied a trend of diversification (see Fig.2). Between 2005 and 2007, Chinese ODI was occupied mainly by metal industry and energy industry, but dominated by metal industry. The investment in energy industry started to occur in 2007 and kept climbing up, and its investment volume exceeded that of metal industry after 2009 and dominated Chinese ODI in Australia. Originating from 2009 when

\footnotetext{
${ }^{4} \mathrm{Up}$ until the second quarter of 2016, Chinese GDP growth rate has decreased to $6.7 \%$, the lowest point since 2009 .

${ }^{5}$ When the productivity level is high, in this scenario, ample products are produced and supplied to the society, and the majority of products are in the position of surplus instead of shortage, together with productivity surplus, so that consumers hold the option, where the market acts as the buyer's market. With the ratio of the third industry increasing, consumption structure accelerates, and the consumption patterns reveal diversification tendency. In this case, in the conflict between production and consumption, consumption dominates this conflict, and productivity as a result cannot be further developed without consumption expansion.See F. Chi in: Understand the "New Normal" of Chinese Economy, edited by China Workers Publishing House, Beijing (2015), p. 302.

${ }^{6} \mathrm{ACT}$ is geographically located inside NSW, where Canberra (the Australian capital) is located, therefore the political central area. Because of political and economic separation, ACT usually has less frequent trading activities.
} 
industries of real estate, finance began to be invested in, Chinese ODI in Australia presented its trend of diversification, which was even manifest in 2014 when industries including real estate, finance, transport, agriculture, tourism, entertainments were covered.

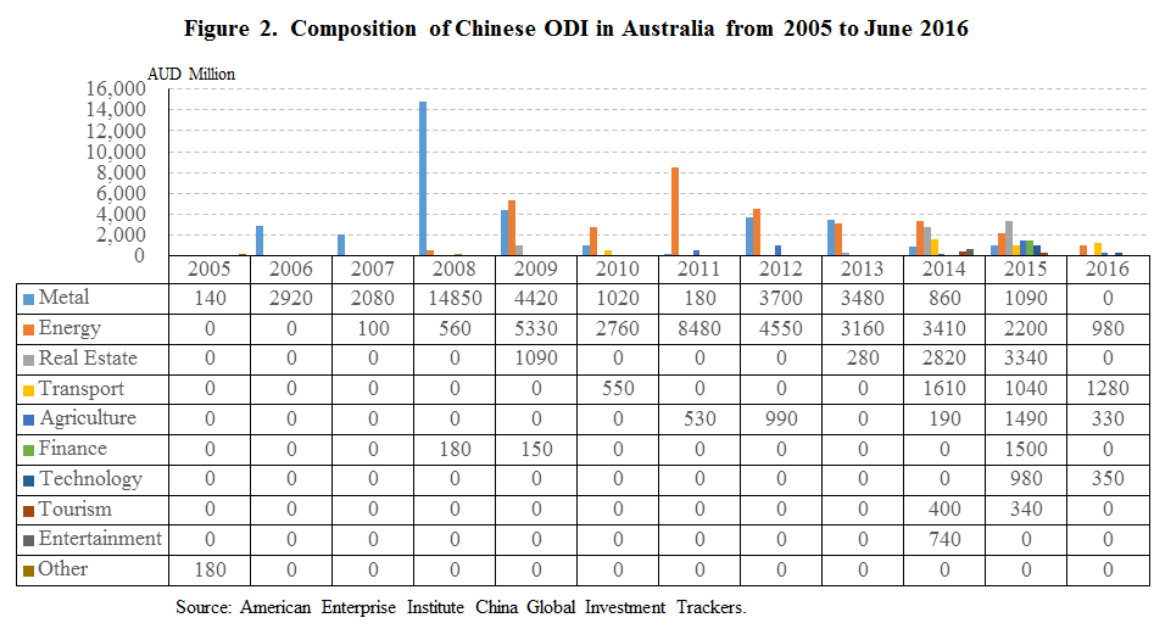

It shall be noticed that the foreign investments in Australian real estates from China rose sharply since 2014, and its investment volume was higher than that of any other industry in 2015. On the contrary, Chinese foreign investments in Australian metal industry and Australian energy industry tended to go down since 2013 and 2015 individually. At present, metal industry, energy industry and real estate principally share the majority of volume and ratio of Chinese ODI in Australia.

In addition to the industrial diversification, the investing principals have also shown a tendency of diversification.In 2015, the investment value of state-owned enterprises(SOEs) was slightly lower than that of the non-SOEs, but the latter occupied almost $80 \%$ of total number of deals completed far beyond that of SOEs.In spite of the investing principals diversifying tendency, nonetheless, Chinese SOEs still take the majority of the accumulated investment. Some Australian have worried about it that excessive Chinese ODI in Australia and the control of Australian resources resulting from it are likely to let Chinese government indirectly interfere Australian politics. Factors including issues of populism like this and the particular characteristic of Chinese foreign investment ownership (like SOEs' dominance) have constituted "a source of political confusion in Australian policy development and in the Chinese perception of Australian policy"[6].Also, Lou (2014) pointed similar obstacles of trades out[7]. As a consequence, it becomes a realistic issue faced by Chinese government andChinese foreign tradehow to stimulate Chinese non-SOEs to invest abroad in order to balance the ratio of SOEs' participation with that of non-SOEs' participation in foreign trades.

\section{Strategies and Recommendations for Improvement}

\subsection{Promote the Diversification}

To improve the imbalanced industrial allocation of Chinese ODI in Australia, thediversification development shall be promoted further, with the target of investment moved towards other industries with investing potential.In recent years, seen from the perspective of Australian industry as well as demand and supply, Australian agricultural products (such as milk, wine, fruits) have been increasingly popularized among Chinese consumers. Australia needs FDI from countries like China to make up for its lack of deposits and capital to develop Australian economy [8].

Besides, with the tourists visiting Australia increasing year by year, Australian government has got down to the focus on and the input in the relevant industries surrounding tourism industry including tourism, transport, human resources. Additionally, natural gas resource has also long been an 
abundant natural resource in Australia while remaining undeveloped, providing potential investing opportunities. Thus, in the current situation where global economy is weak and the development of metal and energy industry is constrained, targeting at other various industries to make diversified investments can not only satisfy the Australian demand for foreign investment input andexpand Chinese ODI in Australia, but it can also promote both countries' economy development.

\subsection{Strengthen the Knowledge about Australian Foreign Policies and Regulations}

In order to reduce the managerial difficulties caused by differences between Chinese regime and Australian regime, Chinese investing enterprises shall get a ready knowledge of multiple Australian local regulations as well as motivations and constrains of Australian foreign policies. According to $<$ Australia's Foreign Investment Policy>, although foreign investments are welcomed by Australian Government, but in sensitive areas like aviation, shipping, media, telecommunications ${ }^{7}$ Australian government has imposed some limitations on the investments [9].In relation to other industries like real estate, prior to investing in these areas, related constrains as well as the political and economic environment shall be taken into consideration as well. Because of the high return generated from investing in real estates in Sydney, Melbourne, etc. in recent years, a flock of foreign investors have turned to invest in real estates and then bid up the local house prices. Solely in Sydney, as can be surveyed, nearly one third of the total real estate assets are owned by foreigners. Consequently, Australian government has been releasing increasingly strict policies on foreign ownership of Australian real estates. When considering the preparation for the investments in these areas, Chinese enterprises are suggested to notice constrains ruled in relevant Australian policies.

\subsection{Encourage PrivateEnterprises to "Go Global"}

To improve the situation where Chinese SOEs dominate ODI and ease the negative influence of populism resulting from it, Chinese government shall release more favorable policies for private enterprises (as well as JVs) investing abroad [10] to actively motivate those enterprises to "go globally". Because private enterprises are characterized by high operating flexibility and adaptability, by contrast, these enterprises are more likely to adapt to the local market regime after going abroad, of which the characteristics and flexibility can possibly reduce or eliminate the negative influence of political uncertainties brought by huge amounts of SOEs' ODI.

As for the realistic issues surrounding the rise of Australian populism caused by Chinese SOEs' ODI dominance, Australian government meanwhile shall set an examining framework for foreign investments to fairly treat Chinese SOEs' ODI in Australia, and official consultations and meetings of Chinese and Australian governments are expected to be arranged more frequently on discussing issues of "scrutiny facilitation of competition, corporate governance and financial transparency" surrounding Chinese SOEs[6].

\section{Conclusion and Prospects}

For long, Australia has been famous for its abundant natural resources reservation around the world. As Chinese national economy blooming and income level being enhanced, Chinese consumers' demands for Australian resources and commodities have been expanding. Under the support of related favorable policies of Chinese and Australian governments, in recent years, those demands have got satisfied through investments and trades. Sino-Australian mutual investments and trades have effectively promoted Australian economic development, in which Chinese ODI in Australia has played a vital role.

\footnotetext{
${ }^{7}$ In accordance to the latest version of <Australia's Foreign Investment Policy $>$, foreign persons must get approval before acquiring a substantial interest (at least 20\%) in an Australian entity that is valued above 252 AUD million, especially for the investments in sensitive businesses including media, telecommunications, transport, defenseand military related industries as well as the extraction of uranium or the operation of nuclear facilities.
} 
However, with Chinese ODI in Australia developing, some realistic issues have also been exposed.Up till now, the dominance of Chinese ODI in Australia belongs to metal industry and energy industry, yet the potential of other industries as well as the regions where these industries are distributed still have not been aware of and remain undeveloped, thus extremely imbalanced allocations in industries and geographical regions. Moreover, Chinese SOEs are still the major investing principals, so that Australian somewhat resist activities of Chinese ODI in Australia, which affects Chinese ODI in Australia negatively.

As a solution to these problems, Chinese enterprises shall target on industries with great investing potential such as agriculture, infrastructure, transport, tourism as well as the areas where those industries are, instead of the only concentration on metal industry and energy industry. Additionally, during preparation prior to the investments, to reduce or avoid investing risks that are caused by the differences of Chinese and Australian regimes and regulations, Chinese enterprises shall be aware of Australian policies of foreign investments, political and economic environment and the changes of them. Also, Chinese government should bring forward more encouraging policies for non-SOEs investing abroad.

Seen from the need of economic development of both countries and the long-term interest, the prospect of Chinese ODI in Australia is expected to be continuously affirmative. On the one hand, Chinese government will continue encouraging the Chinese enterprises to invest overseas. With farther Chinese domestic income level enhancement, together with the development of globalization, the demands of Chinese consumers for overseas commodities, especially Australian products, will continue growing up. On another, Australian government will still be willing to keep its door open for FDI including Chinese FDI to stimulate its economy. Besides, Australian government in the future will keep developing other regions other than NSW and VIC further. There exists a great probability that Australian government may consider transforming industrial structure in remote regions to boom the local economy and may even propose more favorable policies for foreigners' immigrations and investing in those regions. Therefore, analyzed from both sides, there still exista great potential and a prosperous prospect for Chinese ODI in Australia.

\section{References}

[1] Information on $<$ https://www.cia.gov/library/publicationsthe-world-factbook/geos/as.html $>$.

[2] E. Lim\& M. Spence in: Chinese Economy Medium-to-Long Term Development and Transformation, edited by China CITIC Press, Beijing (2011), p. 5-7.

[3] F. Chi in: Understand the "New Normal" of Chinese Economy, edited by China WorkersPublishing House, Beijing (2015), p. 299-302.

[4] Information on $<\mathrm{http}: / /$ us.spindices.com/>.

[5] Ministry of Commerce of the People's Republic of China, National Bureau of Statistics of the People's Republic of China, and State Administration of Foreign Exchange: 2015 Statistical Bulletin of China's Outward Foreign Direct Investment, edited by China Statistics Press, Beijing(2016), p.32.

[6] P. Drysdale: China \& World Economy, Vol. 19 (2011), No.4, p.54-73.

[7] C. Lou: International Business Research, Vol. 35 (2014), No. 195, p.86-96.

[8] G. Zhang: Journal of Beijing Institute of Graphic Communication, Vol. 23 (2015), No. 5, p.58-64.

[9] Information on $<$ http://firb.gov.au/resources/policy-documents/>.

[10] L. ZhouandD. Yan: China Academic Journal Electronic Publishing House, No.6 (2015), p. 114-116. 